\title{
Research on the Customs of festival sports entertainment in Tang Dynasty from Angles of Poems and Proses
}

\author{
Junli $\mathrm{Yu}$ \\ Department of Sports Media and Cultural Studies \\ Xi'an Physical Education University \\ Xi'an 710068,China \\ e-mail: rainlyer@126.com
}

\begin{abstract}
This paper textually investigates festival sports and recreational custom in the Tang Dynasty-its origin, underlying cultural implication, spectacularity and evolution in the Tang Dynasty by document research method. There were a great number of festivals at that time to stage so many colorful festival folk custom activities,such as Man Day, Shangyuan Festival, Shangsi Festival (3rd day of 3rd lunar month),Qingming Festival and Cold Food Day,Dragon Boat Festival, Double Ninth Festival,Lari Festival,Winter Solstice Festival and New Year's Eve.Some Poems and Proses of the Tang Dynasty feature festival sports and recreational activities, presenting clear pictures of such spectacular events and helping preserve our fine folk customs, their rites and more.
\end{abstract}

Keywords - the Tang Dynasty; Sports; Poems and Proses; Festival custom

\section{INTRODUCTION}

As is known to all, the Tang Dynasty witnessed the most powerful and prosperous China, with strong state power, affluent society and spectacular colorful sports activities during festivals. A great many poets then did such a good job in vividly presenting us with the grand scenes of sports events at that time and depicting all features in such events during festivals from various perspectives.

There were a great number of festivals at that time to stage so many colorful festival folk custom activities. Among them, New Year's Day, Beginning of Spring, Man Day, Dark Day (last day of the lunar month), Shangsi Festival (3rd day of 3rd lunar month), Dragon Boat Festival, Qixi Festival (7th day of 7th lunar month), Double Ninth Festival,Winter Solstice Festival and New Year's Eve were celebrated as traditional folk customs carried on as before, while Imperatorial Birth Day, Zhonghe Festival (or Blue Dragon Festival, 2nd day of 2nd lunar month) and Taoist Sanyuan Festivals, as well as lantern lighting on Shangyuan Festival (or Lantern Festival), tomb sweeping on Qingming Festival (or Pure Brightness) and full moon admiration during Mid-Autumn Festival were newly created in the Tang Dynasty. [1] These new and transformational festivals, together with those traditional ones, helped build such a tremendous platform to stage Chinese people and their conduct and manner in the Tang Dynasty.

\section{FESTIVAL SPORTS AND RECREATIONAL CUSTOMS}

\section{A. Ascending a height on Man Day}

Man Day had been celebrated before the Tang Dynasty. Festivals in Jinchu Area records, "Man Day is celebrated on January 7 (lunar calendar)... when people ascend a height and compose poetic proses.'[2] This is the very festival which is themed by human, demonstrating the rich cultural implications of valuing human, birth and new things, which apparently were enriched and developed in such a vigorous society of the Tang Dynasty.

On Man Day, plants begin to sprout in new spring, and if the weather was cooperative, people in the Tang Dynasty usually ascended a height for celebration. Ascending $a$ Height on Man Day by Han Yu reads, "New Year days begin to omen warmer weather until the seventh day when it becomes rather established. ... Relatives and best friends come one after another, and children can also join in. ...Leading such a generous and magnanimous life, we would not be pressed by anyone but stay gentle. "This is a rather detailed depiction of experiences and feeling on Man Day when the author ascended such a height to celebrate.

B. Lantern Watching, Night Tour and Dancing \& Singing on Shangyuan Festival

The $15^{\text {th }}$ day of $1^{\text {st }}$ lunar month is celebrated as Shangyuan Festival (Lantern Festival). Shangyuan Festival was such a grand festival in the Tang Dynasty, celebrated with unprecedented characteristic festival activities like Lantern watching, night tour and dancing \& singing. These activities more often than not lasted all night long, dancing and singing nonstop and even the whole town involved in such a sea of faces, a parade of play and amusement. To facilitate sightseeing tours, singing and dancing, and lantern watching, the imperial court even issued a special order and demand Jinwu (public security official) to prohibit trading during the Festival for a couple of days around the festival.

The night tours and lantern watching customs are shown in some poems of the Tang Dynasty. Shangyuan Festival by $\mathrm{Su}$ Weidao goes, "On show are fireworks and lanterns like flashing flowers on trees everywhere, city moat bridges laid down and iron gate unlocked for the crowd. Behind galloping horses dark dust arises, people found everywhere as far as the full moon shed its light." In the night of 
Shangyuan Festival bustlingly staged were so many things, festival lanterns twinkling, fireworks blooming and light and colors flowing around; how lively the night was! If Only I Could Watch the Lanterns in the Capital on Jan 15 (lunar calendar) by $\mathrm{Li}$ Shangying goes, "Bathed in the moonlight and lamps is the imperial capital, so many are fragrant carriage and precious chariots that they could hardly make their way through"; depicting the three days around Shangyuan Festival during which lanterns were lighted up all night long, people across the town rushing and racing to see festive lanterns in such a crowd that the traffic jammed — vehicles could not make a turn and people could not even face about.

The art of singing and dancing was quite flourishing and fashionable in the Tang Dynasty and among the recreational activities on Shangyuan Festival were singing and dancing. In the first lunar month of Xiantian Year 2 (713 A.D.), "In the night of Shangyuan Festival, the emperor was present at the Gate of Health \& Fortune to watch lanterns, when harem ladies were encouraged to join the crowd to dance and sing, and officials were allowed to watch, for such a whole night". [3] Thousands of maids of honor were dressed up and marked time with folk maids hand in hand, dancing rhythmically and singing nonstop, under the lanterns for three days and nights.

Such a joyous event it was, so unprecedented so to speak. Two Poems on Marking Time with Singing and Dancing before the Emperor in the Night of January 15 (lunar calendar) by Zhang Yue depict the singing and dancing, and such grand luxurious scenes, "Trees are on fire with numerous flames, which seemingly come from the mouth of a dragon, cocks on lotus flowers singing usher into the long lasting spring." Under the resplendent lamplights, people were dancing and singing all night long. This custom lasted until the late Tang Dynasty. On Night-lights on January 15 (lunar calendar) by Zhang $\mathrm{Hu}$ goes, "Doors are opened wide and lamps lighted up around numerous households; this mid-January the imperial capital is in full swing. Three hundreds of maids of honors are dancing, waving long sleeves; the sounds of songs and instruments at that moment are rising up to the heaven." There were as few as 300 dancers and singers at that time, but apparently it was still spectacular, maid of honors dancing and waving sleeves under all lights on in the court, while the audience joined the singers, reaching up to the heaven; such a spectacular scene it was still!

\section{C. $\quad$ Spring Outing on Shangsi Festival}

Shangsi Festival (or Traditional Chinese Women's Day) as a traditional one in ancient China was celebrated on March 3 (lunar calendar) in the Period of Wei, Jin and Southern and Northern Dynasties. People in the Tang Dynasty followed the custom since Wei and Jin, gathering around a little stream and floating a wine cup to drink and compose. Festivals Nearby Imperial Carriage records, "On Shangsi Festival, Tang people across the whole town gather around little streams and drink, as an outing in spring." [4]

Shangsi Festival each year saw warmer and warmer spring in the air, evident everywhere. "On March 3 (lunar calendar) it gets refreshed; around streams in Chang'an (Capital of the Tang Dynasty) gathered are a great many beauties" (Beauties in Outing by Du Fu (712_-770, one of the most famous poet in the Tang Dynasty). On Shangsi Day by Liu Jia goes, "On the Shangsi Day, many people gather around winding streams, in such a crowd as bustling as that downtown in the morning. Old friends who have failed to find each other always come across in here." On the day, all people across the town would go outing; some people might have failed to see each other downtown, but they might come face to face with each other right here; this shows what a grand occasion the Shangsi Festival in the Tang Dynasty was! People went out, bathing and holding rites and ceremonies, playing with waters, appreciating beautiful flowers, and drinking around winding streams; so crowded with people and vehicles in such impressive parades was the whole Chang'an city, and people were bathed in happiness and joy as such that they forgot to return home.

D. Playing Cuju and Cock Fighting, Ancient Wrestling and Tug-Of-War, Riding Swing and Flying Kite During Qingming Festival and Cold Food Day

The $105^{\text {th }}$ or $106^{\text {th }}$ spring day after Winter Solstice Festival each year was celebrated as Cold Food Day, and one or two days after it came Qingming Festival. A Poem on Cold Food Day to Emperor's Order by Zhang Yue goes, "For a long time, people take making fire for cooking during the festival as a taboo until the morning of Qingming Festival." The two festivals were so close that they shared similar recreational activities in the Tang Dynasty, like playing Cuju and cock fighting, ancient wrestling and tug-of-war, doing swing and kite.

The favorite game for emperors and ministers in the Tang Dynasty on the Cold Food Day was playing Cuju. Old Book of Tang Dynasty: biographic sketch of Emperor Dezong (first part) records, "On the Cold Food Festival (in February of Zhenyuan Year 1), the emperor played Cuju with many generals in the adytum compound." "The emperor was fond of playing Cuju, for it was a good way to promote folk customs." [5] Thus, Cuju was quite popular and played everywhere at that time. In the poem Observations in the East on Cold Food Day, Wang Wei wrote, "Cuju balls jump over flying birds now and then", while Wei Yingwu described on the Cold Food Festival, "You can hear pounding drums from afar; the corps are playing Cuju and have fun." (A Poem Composed in the North Tower after the Cold Food Day)

In addition to Cuju games in Chang'an and the Corps, Bai Juyi (772-846, one of the most famous poets in the Tang Dynasty) also witnessed the popular Cuju Game on the Cold Food Festival in Luoyang. In his poem Composed in Luoyang on the Cold Food Day, Bai Juyi writes, "People play Cuju dust-free; clear days come after fire-extinguishing rain." There is also a poem tilted Composed When Drunk Outside the City of Fuzhou on Cold Food Day by Wei Zhuang. So many poets in different places and different years of the Tang Dynasty composed such poems that clearly show around Cold Food and Qingming Festivals 
people across the country played such a healthy ball game.

Cuju, as a folk activity around Cold Food Day, could be played for self-enjoyment only, or even performed in front of a large audience. A Palace Poem by Wang Jian depicts a skill maid of honor from a kind of imperial institute on her way to perform Cuju in the imperial palace, when she could not sleep well but take her dress and makeup done the day before and made their way to the flower trees inside the imperial palace the first thing in the morning. She was all for those good ball performances which may please the emperor and help her win some reward. These lines, as few as 28 characters, vividly depict the vigorous life of Cuju maids of honor in the Tang Dynasty. It also works to reflect the tradition in the Tang Dynasty that Cuju maids of honor came to the imperial place around Cold Food Day for Cuju show to entertain the Emperor.

Also popular at that time were wrestling, tug-of-war and the like activities. During the Cold Food and Qing Ming Festivals in Kaicheng Year 4 (839 A.D.), Emperor Wenzong made a personal appearance the Office Building of Diligence, to "watch wrestling and Cuju games". "Emperor Zhongzong once arrived at the Liyuan playground, and ordered near servant officials to play tug-of-war.'[6] Civil and military ministers and emperor's son-in-laws all got involved, and some senior ones were stumbled down over the rope, but could not manage to stand up. The emperor burst into laughter, and asked the guards around him to assist them to their feet."

Around Cold Food Day and Qingming Festival, there was another popular game- -swing. A poem titled Qingming (Pure Brightness) by Du Fu reads, "The same swing custom is shared everywhere". This shows how popular the swing game was among the people. Bai Juyi mentioned swing riding for many times, "Upon clearing up, swings are set up here and there"; "slender-waisted ladies are riding a swing, swaying up in the air". In a poem titled Happy Days around Mid Spring to Share, Liu Yuxi also depicts, "Swings are competing, and dragging colored ropes back and forth." Cold Food by Li Shanfu reads, "Swings are carrying the girls over the fence", which depicts such heroic postures of girls playing the swing. Liu Zhongyong wrote, "The swings are dancing with willow catkin" (Complete Tang Poems: Vol. 257), describing the picture in which swings are dancing endless when willow catkin is flying in spring.

Another scene commonly seen in everyday life in the Tang Dynasty was spring outing and kite-playing around Qingming Festival. In the poem titled Shangsi Festival, Tang Yanqian wrote, "Shangsi is followed by Cold Food Day, when kites are played here and there in the morning. People are braving fire-extinguishing drizzling, outing around for fun." Shangsi Day by Yuan Zhen reads, "This day whole families are out for excursion." Outing East of the Town in the Morning on the Cold Food Day and the like poems by Luo Yin presents people with scenarios that during Cold Food and Qingming Festivals in the Tang Dynasty, no matter in the North or South, people joined the crowds and went out closer to nature, walking around to pick green leaves, smell flowers and appreciate landscape. Doing sight-seeing are also those poets and men of letters themselves, and princes, princesses, and other gentlemen and ladies in their work, who were so indulged in such beautiful scenes that they always forgot to return home.

\section{E. Dragon-boat Racing and Herb Picking Contest} on Dragon Boat Festival

Dragon-boat Festival mainly features dragon-boat racing. In Festivals in Jinchu Area, Du Gongzhan related boat racing to Qu Yuan (a well-known patriotic poet in the Period of Warring States), remarking, "The boat racing on May 5 (lunar calendar) celebrated these days is an old custom to recall $\mathrm{Qu}$ Yuan, who threw himself into Miluo River upon his motherland was conquered, which made people so sad that they mourned over his death by boating to save him." [7]

The legend of boat-racing originating from $\mathrm{Qu}$ Yuan was generally accepted in the Tang Dynasty. Most poets in the Tang Dynasty believed that the boat racing was meant to mourn over Qu Yuan's death; for example, Watching Boat-Racing by Chu Guangxi reads, "Official Qu Yuan sank himself into a river in the State of Chu (a kingdom in the Period of Warring States), thus more than one thousand years of sacrifices has been offered by compatriots to mourn his death." What's more, poems like Boat Racing Song by Liu Yuxi, Four 4-line Poems to Magistrate Yang from Wanzhou by Bai Juyi and Unexpectedly Composed by the Lake During Boat Racing by Li Qunyu all relate the event to the sad story that Qu Yuan sank into water.

In the Tang Dynasty, however, dragon-boat racing was not only meant to recall $\mathrm{Qu}$ Yuan, but also became a competitive sports event, an impressively powerful and vigorous one. Ode to Boat Racing by Fan Zao reads, "It is on the Dragon Boat Festival in mid-summer when candidate boats are placed in slotted channels to compete and decide the best one in water. The boats are painted in impressive colors and the one which gets the colored marker set up at the destination first wins." (Complete Tang Proses,Vol. 957) A great many poems by $\mathrm{Xu}$ Yanbo, Zhang Yue, Chu Guangxi, Zhang Jianfeng, Wang Jian, Yuan Zhen, Bai Juyi, Liu Yuxi, Fan Zao, and Li Qunyu in the Tang Dynasty depict dragon-boat racing presenting us with such lively vigorous pictures. Song to Boat Racing by Zhang Jianfeng also relates the grand occasion of a boat race and its intense competition during the Dragon-boat Festival, incisively and vividly depicting such a spectacular scene of dragon-boat racing.

In addition to boat racing, people also played games like herb picking contest around the Festival. Festivals in Jinchu Area records, "On May 5, people tread in the field to collect all kinds of herbs, which is also known as the game of herb picking contest." This is also recorded in many poems in the Tang Dynasty. Lantern Flowers by Si Kongtu goes, "It would be such a happy thing to join the herb picking contest tomorrow morning, so she was drawing her eyebrows below a flowered lantern" Inscription on the Wall of Poule Wang Funiang by Sun Qi reads, "She lost the herb collecting contest to a neighbor girl for no reason whatsoever; her precious jewelry was even taken off." All these lyric lines are just the cases in points to demonstrate the event. 


\section{F. Ascending a Height on Double Ninth Festival}

The custom of ascending a height on Double Ninth Festival had been celebrated for a long time; as remarked in Festivals in Jinchu Area, "On September 9, all walks of life go to the wild together doing festive picnic things." On this day every year, emperors in the Tang Dynasty would ascend the Ci'en Pagoda as a rule. For example, Xiao Zhizhong contributed A Poem on Ci'en Pagoda Ascending upon the Emperor's Order; scholars and civilians either ascended a height mountain, pavilion or city gate tower or a Buddhist pagoda.

September (lunar calendar) in autumn provides such an invigorating climate that Confucius said, "We gentlemen shall compose when ascending a height". Poets in the Tang Dynasty composed much more poems around this festival than those around any other festival. A great many great poets like Li Bai (701 762, one of the most famous poets in the Tang Dynasty), Zhang Jiuling, Meng Haoran, Dugu Ji, Qian Qi, Linghu Chu, Rong Yu, Zhao Gu, Ying Xingxian, Li Qunyu, Quan Deyu and Yu Xuanji — all made ode to this festival over and over again. Li Bai composed, "It is so clear on September 9 that we ascend height to peer clouds in autumn". During this festival, the emperor and ministers did not only mount up, but composed poetical works in contest to add more flavors to the festival. On the Double Ninth Festival in Jinglong Year 3, the emperor issued a decree to virtuous relatives and ordered officials of virtue in the court" to ascend a height drinking and composing poems, "Everyone is supposed to compose tetrameter rhymed five-character quatrains, and the last one left behind shall be punished to drink a full cup of liquor" (Complete Tang Proses, Vol. 17).

Some men of letters who had left their hometown would ascend a height and expressed their nostalgia, or diverted themselves from worries the first thing there. Wang Wei once composed, "I know from afar that brothers are ascending a height, all wearing cornel flowers, with only one person absent", which expresses the poet's loneliness in an alien land and slight depression deep down.

\section{G. Hunting on Lari Festival}

Since ancient times, "Lari Festival" has been a festival to offer sacrifice to various gods at the end of the year. In the Tang Dynasty, it was a custom to hunt this day, which was not only meant to meet the demand for sacrifice, but also to reveal the hunting loving warrior spirit then. Ode to General Gai at Yumen Pass (literally, Jade Gate Pass) by Cen Sen in the high Tang reads, "On the Lari Festival, the general rode to hunt south of the city, and shot and caught such a millennium fox" .Hunting a fox on the Lari Festival in the army is clearly depicted here. In his poem titled Hunting On Lari Festival, Yao He in the mid and late periods of the Tang Dynasty also mentioned one of his collective hunting events to meet the demand for sacrifice on that festival when he was governor of Jin Zhou. People in the Central Plains did not hunt on the day alone, and some ethic groups like Yao in the South also maintained such a custom. When Liu Yuxi served as governor of Lian Zhou, he witnessed Yao people's hunting event, as was such a huge picture showcased in his poem titled Viewing Yao People's Hunting on the Western Hill in Lianzhou on Lari Festival.

Originally, hunting on Lari Festival was meant to meet the demand for sacrifice, train soldiers or just for fun, but some local provinces or prefectures authorities tended to overdo and kill all, so as to get hands on prey to please the superior. Emperor Xianzong was very much astounded at such slaughters and observed, "Every Lari Festival recent years, I heard some prefectures and counties, to take something to the capital, catch and raise foxes and hares to serve as tributes" (Complete Tang Proses,Vol. 60); therefore he issued the Fox \& Hare Hunting Forbidding Decree.

\section{H. Singing and Dancing to Expel Demon on the New Year's EVE}

At the end of the year in the Tang Dynasty, many activities were rather ardent and ceremonious, among which main recreational programs like demon expelling and singing \& dancing have been carried on to date. Demon expelling was originally a kind of superstition rite to drive out plague and ghosts, and by the Tang Dynasty it had also become a gala for recreational purpose on New Year's Eve. As shown in proses like Composed on New Year's Eve by Xue Neng and On New Year's Eve by Yao He. people in the Tang Dynasty wear masks and dressed up like gods or ghosts in bizarre dresses holding some instruments and shouting and dancing to expel demons, as was so lively and bustling and particularly in the imperial court was very spectacular and impressive. The tremendous "major demon expelling" rite held by the imperial family in the Tang Dynasty involved as many as 500 people. This Gala marked the arrival of a New Year, with such climax of New Year's Eve and New Year celebration.

In addition to sports activities during the above traditional festivals in the Tang Dynasty, there were also other various sports and recreational activities like horse dancing on Imperatorial Birth Day, Taoist temple visits and acrobatics on Zhongyuan Festival. Horse dancing on the Long Live Birthday of Emperor Xuanzong, in particular showcased in a concentrated manner the ardent, bold and unrestrained scene of the prosperous Tang Dynasty, as reflected by "On the Day horses dancing with knees bent and cups held in their mouths, expressing people's best wishes - Long live Emperor" (Lyrics on Horse Dancing by Zhang Yue).

\section{CONCLUSION}

Under the impact of profound cultural psychology and folk custom, the above days and festivals were established as specific occasions for people to conduct one or several sports and recreational activities in the Tang Dynasty. Those rejoicing activities held annually helped people to find some shelters for their rather exhausted hearts, and to get depression off their chest so to speak. Voltaire praised the spiritual life of Chinese people and remarked, "Chinese people might not boast of any consummate arts form of spirituality, but apparently they quite enjoy what they are familiar with. In short, they enjoy happiness in line with human needs"[8].Indeed, sightseeing tour and dancing \& 
singing on Shangyuan Festival, excursion on Shangsi Festival, Cuju playing, swing riding and tug-of-war during Qingming and Cold Food Festivals, dragon-boat racing on Dragon-Boast Festival and Ascending a Height on Double Ninth Festival - they all provided seasonal sports activities for people in the Tang Dynasty to entertain divert and communicate with themselves and each other. Sports and creational customs staged in these days and festivals vividly showcased in a concentrated manner people's attitude towards life-bold and generous, optimistic and loving, fulfilled and indulged. Analyzing these festive sports involving poetic proses in the Tang Dynasty, thus we can know the development of sports culture itself better. These poetic works actually carry and reflect the change of fashion, atmosphere and society in the Tang Dynasty.

\section{ACKNOWLEDGMENT}

The author gratefully acknowledge the financial support of National Social Science Foundation of China(Grant No.12XZW010), the Ministry of education Humanities and Social Science Foundation of China(11YJC751107) and the Sports Culture Development Center of State Physical
Cultural Administration research Foundation of China(2012-2014TYWHY207).

\section{REFERENCES}

[1] Z.X.Zhang, "Festivals in the Tang Dynasty",Literature and History, vol. 37 1993,pp. 65-92 .

[2] Z.L.Liang, Festivals in Jinchu Areas, as edited and proofread by Yan, JIANG,Hunan: Yuelu Publishing House, 1986,p. 9.

[3] X.Liu et. al. Old Book of Tang Dynasty, Beijing: Zhuanghua Book Company, 1975,p.151.

[4] D.Y.Peng, Shantang sikao, Complete Library in Four Collections of Imperial Treasures, Vol. 974,p.157.

[5] G.SiMa, History as A Mirror, as remarked and noted by XIAO Fang; SUN Yuwen, Beijing: China Friendship Publishing Company, 1993,p. 698.

[6] Y.Feng, Commentary on Feng's Record of What He Sees and Hears, as noted by ZHAO Zhenxing , Beijing: Zhonghua Book Company, 2005,p. 49.

[7] Z.L.Liang, Festivals in Jinchu Areas, as edited and proofread by JIANG Yan, Hunan: Yuelu Publishing House, 1986,p. 36.

[8] Voltaire, On Customs, as translated by LIANG Shouqiang, Beijing: Commercial Press, 1995,p.461 (in Chinese). 